José Frederico Marques, professor catedrático José Frederico Marques

de direito judiciário civil, na Faculdade Paulista de Direito e Pontifícia Universidade Católica de

São Paulo - PUC; livre-docente de direito judiciário penal na Faculdade de Direito da Universidade de São Paulo - USP e desembargador aposentado do Tribunal de Justiça de São Paulo.

\title{
O despacho saneador no projeto do Código de Processo Penal
}

1. O despacho saneador foi transplantado do processo civil português, para o nosso primeiro código nacional de processo civil (o Código de 1939), tendo sido recebido com entusiástica aceitação. Eis o que a respeito escreveu Jacy de Assis: "O despacho saneador foi o instituto que mais interesse despertou no Código de 1939 pelo conteúdo renovador que nele se continha.

Couture e Sentis Mellendo o elogiaram com entusiasmo; Liebman escreveu sobre ele um estudo notável que orientou a jurisprudência e a doutrina; Niceto Alcalá-Zamora y Castillo, no seu excelente Veintecinco años de evolución del derecho procesal, o registrou como um dos 'aciertos evidentes' dos processos português e brasileiro.

Muitos juristas e estudiosos brasileiros o versaram em livros ou estudos e Eliezer Rosa, desculpando-se pela imagem enfática, elevou-o à dignidade de epopéia, processual, tal a sua beleza e grandeza funcionais".

Todavia, no Código de processo civil vigente, embora fosse mantido o instituto, quiseram afastarlhe o nomen iuris, isto é, a denominação já agora consagrada - de despacho saneador.

Assim é que, promulgado o Código de processo civil - CPP, através da lei 5.869, de 11 de janeiro de 1973 , o então ministro Alfredo Buzaid enviou mensagem ao Congresso, para corrigir alguns textos, e da qual resultou a lei n. 5.925, de 1 de outubro de 1973, introduzindo várias emendas, dentre elas a que consistiu justamente em alterar a rubrica da seção III, capítulo V, do livro I, substituindo "Do despacho saneador", por "Do saneamento do processo."

Contudo, apesar de se ter procurado, com a emenda, eliminar a expressão 'despacho saneador', por inadvertência ela continuou no art. 338. Ė o que explica Theotônio Negrão:

"Na redação primitiva do CPC, os arts. 22, 264 § único, 331, 338 e a rubrica desta Seção III falavam em 'despacho saneador'. Como esse despacho, segundo a técnica adotada no art. 162, é, na realidade, uma decisão interlocutória (embora existem acórdãos considerando-a mero despacho ordinatório e, em conseqüência, irrecorrível, conquanto passível de correicão parcial), a lei 5.925, de 1 de outubro de 1973, evitou a expressão e alterou os textos que a mencionavam, à exceção do art. 338 , que, por inadvertência, continuou a falar em 'despacho saneador"'.

Por essa razão, Jacy de Assis estranha que na doutrina se prossiga falando em despacho saneador, como ocorre em livros de Luiz Antônio de Andrade, José Carlos Barbosa Moreira, Calmon dos Passos e outros.

2. Quando se estava elaborando o projeto de Código de processo penal - CPP, houve igual preocupação, pelo que se a comissão houve por bem propor que se substituísse 'despacho saneador' por 'ato decisório de saneamento'.

Insurgimo-nos contra essa proposta, escrevendo o seguinte: 'Despacho saneador' é nomen iuris que entrou em nossa terminologia processual; de maneirä definitiva. 
Não importa sąber se se configura como despacho, ou decisão, pois a verdade é que quando se fala em 'despacho saneador' projeta-se o nomen iuris como num só todo: ele não é despacho ou decisão, e sim despacho saneador. Não se dissociam os vocábulos que o compõem; ao reverso, eles aglutinamse constituindo assim 'ato judicial específico' com a denominação consagrada de deśpacho saneador. Demais, c Código de processo civil - CPC o emprega de modo expresso, no art. 338, com o que the deu livre trânsito nas áreas das normas de processo; e na súmula 424, do Supremo Tribunal, também se menciona com todas as letras 'o despacho saneador'. Ele constitui o ato com o que o juiz formaliza o saneamento do processo, isto é, com que declara 'saneado o processo', conforme se vê do art. 331, do Código de processo civil - CPC.

As providências para esse saneamento - que o antecedem - ficam cobertas sob o seu nomen iuris, uma vez que a causa finalis desse atos é o despacho saneador. Sem este não há, como é óbvio, saneamento do processo. Além disso, nele estão contidos atos decisórios e heterogêneos, como se vê dos números I e II, do citado art. 331, do Código de processo civil - CPC. Todos sabem, por isso, o que significa despacho saneador, o que nele se contém e a sua configuração como ato processual específico.

Portanto, por que substituí-lo pela expressão 'ato decisório de saneamento', de nenhuma ressonância no linguajar forense? Para que impor-se essa inovação terminológica, quando temos nomen iuris tão expressivo a constituir - como já foi dito ato processual específico, perfeitamente individualizado em sua forma e conteúdo, que já ganhou foros de cidade na terminologia do direito processual pátrio?

Essas objeções mereceram inteira acolhida pelo que o projeto repudiou a expressão 'ato decisório de saneamento do processo', e manteve a denominação que vem de 1939 - 'despacho saneador'.

Tão fundo penetrou a expressão no linguajar forense de advogados, juízes e membros do ministério público, que se usa constantemente fórmula simplificada: o 'saneador'. E diga-se de passagem, esse qualificativo assim substantivado é muito mais eufônico que saneamento.

3. Feitas essas considerações preliminares, vejamos agora qual a natureza jurídica do despacho saneador.

Evidentemente não é ele um simples despacho, e sim, decisão interlocutória, com a qual o juiz declara admissivel a acusação e estabelece providências para ordenar o ulterior curso do processo.
Há que registrar, primeiramente, que há grande semelhança e afinidade entre o despacho saneador e a sentença de pronúncia. Primeiro, porque têm ambos qualificação não ortodoxa: o saneador não é simples despacho e a pronúncia não alcança as culminâncias de sentença. É que tanto um como outra são decisões interlocutórias, que, por isso mesmo, não põem fim ao processo.

Assim como a pronúncia é proferida porque o juiz não pode absolver nem impronunciar o denunciado, também o despacho saneador é lançado nos autos porque o juiz, diante de processo válido e da lide sem sentença absolutória, tem de pô-lo para frente, declarando-o em ordem e procurando disciplinar o procedimento que se segue a essa decisão.

É, aliás, o que de modo expresso se encontra preceituado no art. 256, do Projeto: "Não sendo o caso de julgamento conforme o estado do processo, o juiz proferirá despacho saneador".

4. No despacho saneador, tal como na pronúncia, declara-se admissível a acusação intentada pelo querelante ou pelo ministério público. É que o juiz só profere o saneador se o processo estiver regular e se acharem presentes as condições da ação. Se faltar justa causa, ou se ocorrer falta insuprivel de pressuposto processual ou de condição para exercício da ação penal, não poderá haver acusação viável e o processo será julgado extinto sem julgamento de mérito, conforme o diz o art. 255, do projeto. E nesse caso, como é óbvio, o juiz não poderá declarar saneado o processo.

No despacho saneador, a declaração de admissibilidade da acusação se encontra consunstanciada no recebimento da denúncia ou queixa, visto que, conforme o que consta do art. 256 , do projeto, "o juiz proferirá despacho saneador em que receberá a denúncia ou queixa".

O recebimento da peça acusatória, portanto, no despacho saneador, equivale à pronúncia. Em ambos, está expresso o resultado do iudicim accusationis, com a declaração da admissibilidade da acusação. E ao inverso, tanto na sentença prevista no art. 255 - do projeto que declara extinto o processo sem julgamento - como na de impronúncia, há a declaração de inadmissibilidade da acusação, pelo que o réu é absolvido da instância. Dizia, por isso, ao comentar a legislação pretérita sobre o júri, o desembargador Edgard de Moura Bittencourt: "a impronúncia nada decide em definitivo em favor do réu, o qual apenas é absolvido da instância."

5. Ao proferir o despacho saneador, cumpre ao juiz ordenar o processo; é o que determina o art. $256, \S 10$, letra a, do projeto. É que, no saneador, o juiz não só declara admissível a acusação e o pro- 
cesso, como também ordena os atos posteriores do processo, encerrando ao mesmo tempo a fase postulatória do procedimento.

O despacho saneador é, assim, um 'divisor de águas', que separa vertentes do procedimento, como ato ad quem da fase postulatória e momento a quo da fase instrutória e decisória.

Por ser saneador, esse ato decisório é proferido depois de ter o juiz escoimado o processo de irregularidade e imperfeições, suprindo as nulidades acaso existentes, ou decretando as insanáveis, mas, na forma do art. 200, "ordenando as providências necessárias" a fim de que os atos anulados sejam repetidos e retificados. O juiz só declara saneado o processo quando este estiver sem defeitos e secundum legem.

Essa operação de limpeza, com a regularização formal do processo, é tarefa que se realiza por escala e que tem no despacho saneador o seu ponto culminante e fundamental. Desde o início do processo, com a apresentação da queixa ou denúncia, vem o juiz, aos poucos, provendo à regularidade do processo.

Depois, no entanto, de apresentada a defesa prévia do réu, a regularização do processo alcança seu ponto culminante, porquanto o juiz declara, com o saneador, que o processo se encontra em ordem para que a causa penal, após a instrução, seja deci- dida e julgada.

Só depois de proferido o despacho saneador pode o processo caminhar para diante a fim de atingir o seu objetivo, que é o de julgar o juiz a lide penal, declarando procedente a acusação - no todo ou em parte - com a condenação do réu, ou declarando-a improcedente, com sentença absolutória.

Por isso mesmo prevê o juiz, no saneador, sobre os atos posteriores do processo, conforme está claro nas regras constantes do art. 256, seus itens e parágrafos do projeto.

6. Inovação de grande relevo será introduzida em nosso processo penal - se aprovado no texto do projeto sobre o despacho saneador - em que se declara, nessa decisão interlocutória, o juiz deve fixar, desde logo, a classificação legal do fato delituoso.

Hoje, a qualificação legal dos fatos imputados ao réu, na denúncia, é de secundária importância, uma vez que, segundo estatui o art. 383, do Código de processo penal - CPP vigente, "o juiz poderá dar ao fato definição jurídica diversa da que constar da queixa ou da denúncia, ainda que, em conseqüência, tenha de aplicar pena mais grave".
No projeto, norma antinômica é que rege o assunto, pois o art. 356"assim dispõe:

"Art. 356 - O juiz não pode dar ao fato definição legal diversa da que constar do despacho saneador (art. 256, $\S 1 \%$, letra a ), salvo se: I - beneficiar o acusado (parágrafo único do art. 355); II tiver havido aditamento da acusação"

Essa mudança de orientação foi imposta tendo em vista a plenitude do direito de defesa - que é cânon e postulado constitucional e para garantia mais sólida e eficiente ao direito de liberdade.

Há a observar, primeiramente, da dificuldade (e mesmo impossibilidade) de estabelecer-se um critério geral a respeito da chamada identidade do fato. G. Bettiol depois de tentá-lo fazer em festejada monografia sobre a correlação entre a sentença e a acusação, chega, mais tarde, à melancólica conclusão de que sua opinião não podia prevalacer, tanto que assim se expressou: "hoje duvidamos da possibilidade de se compor um critério geral de identidade, tendo presente apenas a natureza formal ou substancial dos fatos focalizados no processo. Tem razão, por isso, os que sustentavam a inexistência de um tal critério, pelo que preconizavam que se resolvesse a questão caso por caso, como, por exemplo, Manzini". E acrescenta o saudoso penalista italiano: "caso por caso, não porém com base no arbítrio do magistrado (o direito é negação do arbítrio individual), mas na pauta de um critério informador do processo penal como instrumento de defesa da liberdade individual. E esse critério outro não pode ser que o do reconhecimento do direito de defesa do acusado, o qual deve ser colocado em condições de poder responder plenamente à imputação contra ele dirigida".

De outra parte, as controvérsias a respeito da identidade ou diversidade no tocante a fato no direito processual e a fato no direito penal tornam ainda mais frágeis os alicerces em que se arrima a norma do art. 383, do Código de processo penal - CPP - vigente.

Por fim, estamos com Zironda, quando afirmou que não se pode, absolutamente, fazer corresponder o fato imputado a título diverso do crime que de inicio se Ihe atribuiu, sem mudar o mesmo fato.

As dificuldades enfrentadas pela doutrina processual na tentativa de estabelecer conceituação unívoca sobre a identidade do fato acabaram por desembocar em critérios subjetivos e variáveis a respeito do assunto, com grave dano à defesa do réu e a seu ius libertatis.

Com a regra adotada no projeto, essas incertezas desaparecem e o direito de defesa pode ser exercido amplamente. Com a qualificação legal dos 
fatos permanecendo imutável, sabe o réu, com precisão, do que está sendo acusado, sem necessidade de que, ao defender-se, seja levado a expender longas e difíceis alegações, em prol de sua liberdade, a fim de procurar na imputação contida na denúncia final o crime que the pode ser atribuído.

De outra parte, a norma do art. 356, do projeto, não constituirá instrumento de alteração da realidade, a impedir que, antes as provas colhidas nos autos, não se altere a qualificação legal do fato delituoso. É que, nesse caso, a denúncia deve ser aditada pelo órgão da acusação (art. $233, n$. I, do projeto), o que pode ocorrer até mesmo na audiência de instrução e julgamento (art. 350).

Minhas senhoras e meus senhores, são estes, em nosso entender, os aspectos de maior projeção ou realce no tocante ao despacho saneador tal como disciplinado e previsto no projeto do Código de processo penal - CPP.

A introdução desse instituto nos procedimentos penais, com os preceitos de outros que o complementam, se nos afigura acertada e de grande alcance, uma vez que permitirá ao réu defender-se plenamente desde o início da relação processual, permitindo assim que só se mantenha a persecução penal, com os ulteriores atos do procedimento até final, quando houver acusação razoável e o que Beling denominava de processus instus. Desse modo se assegura com mais eficiência a defesa do direito de liberdade, bem como do status dignitatis do acusado. 